Volume 7

Number 2 Student Articles Edition

Article 1

3-26-2021

\title{
Givens v. Mountain Valley Pipeline, LLC and the Unresolved Circuit Split
}

Karen Alday

kealday@gmail.com

Follow this and additional works at: https://scholarship.law.tamu.edu/journal-of-property-law

Part of the Oil, Gas, and Mineral Law Commons, and the Property Law and Real Estate Commons

\section{Recommended Citation}

Karen Alday, Givens v. Mountain Valley Pipeline, LLC and the Unresolved Circuit Split, 7 Tex. A\&M J. Prop. L. 137 (2021).

Available at: https://doi.org/10.37419/JPL.V7.I2.1

This Student Article is brought to you for free and open access by Texas A\&M Law Scholarship. It has been accepted for inclusion in Texas A\&M Journal of Property Law by an authorized editor of Texas A\&M Law Scholarship. For more information, please contact aretteen@law.tamu.edu. 


\title{
GiVEnS V. Mountain VALLEY PIPELINE, LLC AND THE UNRESOLVED CIRCUIT SPLIT
}

\author{
Karen E. Alday ${ }^{\dagger}$
}

\begin{abstract}
The natural gas industry is central to the United States economy. However, due to vague regulations and judicial leniency, natural gas pipeline companies have almost zero restraint in exercising eminent domain. Their current operations mirror that of the federal government's authority to exercise immediate possession. Recently, landowners have contested the pipeline industry's authority to exercise eminent domain, which has developed into a circuit split. The Fourth Circuit, and the six other circuits that have followed suit, hold that pipeline companies have the substantive right to immediate entry and are entitled to a preliminary injunction before a trial on just compensation. The Seventh Circuit holds that the courts do not have the authority to grant immediate entry, and the pipeline company must complete the entire standard condemnation process before entering the property. In 2019, there were two attempts to bring this issue before the Supreme Court, and both attempts failed. This Note evaluates the most recent attempt in Givens v. Mountain Valley Pipeline, LLC and argues that the Supreme Court should address this issue and adopt the Seventh Circuit approach.
\end{abstract}

DOI: https://doi.org/10.37419/JPL.V7.I2.1

$\dagger$ J.D. Candidate, Texas A\&M University School of Law, Spring 2021. This Note is dedicated to my mother, my best friend who passed away shortly before I started writing this. I would not be the woman, wife, daughter, sister, or friend I am today without her. I would like to thank my dad for pushing me outside my comfort zone, my brother for keeping me laughing, and most importantly my husband, Christopher, for always believing in me. Lastly, I am grateful for the Texas A\&M Law School community, specifically, Professor Carol Pauli, Professor Neil Sobol, my Note and Comment Editor Eddy Garza, and my Executive Editor Alexandra Lizano for their encouragement and keeping me on track throughout this challenging process. 


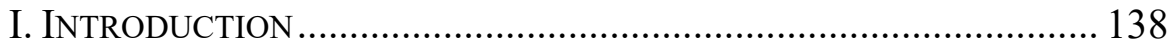

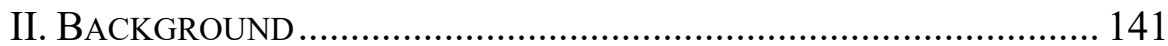

A. The Natural Gas Act and Eminent Domain.................... 141

B. The Development of Pipeline v. Property

Owner Cases................................................................. 145

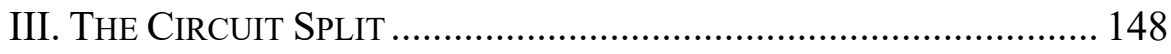

A. The Fourth Circuit Sage Approach ………………......... 148

B. The Seventh Circuit Northern Border Pipeline

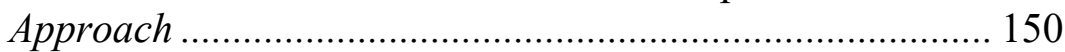

C. The Supreme Court Should Provide Clarity .................... 151

IV. SUPREME COURT DEVELOPMENTS ............................................. 153

A. Recent Supreme Court Attempts ...................................... 153

B. The Supreme Court should adopt the Seventh

Circuit Approach ……………………............................ 157

1. The NGA Does Not Authorize Immediate

Possession ..................................................................... 157

2. Courts Have Exceeded the Limits of Equity.............. 159

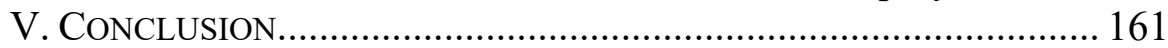

\section{INTRODUCTION}

Most couples spend decades planning and saving for retirement. They will plan almost their entire lives around their retirement goals and spend their life savings on making that dream a reality. ${ }^{1}$ For one couple, that meant purchasing a farm in rural Virginia. ${ }^{2}$ For over a decade, they used this farm as a source of income as they approached retirement by growing crops, raising cattle, and renting out the home on the property. ${ }^{3}$ However, what they initially believed to be a safe investment started slipping through their hands in 2014. ${ }^{4}$ Mountain Valley Pipeline, LLC began building a 303-mile pipeline with plans to run the pipeline directly through the couple's

\footnotetext{
1. Ultimate guide to retirement, CNN MONEY https://money.cnn.com/retirement/guide/basics_basics.moneymag/index.htm [https://perma.cc/EM9T-K9L7].

2. Petition for Writ of Certiorari at 5, Givens v. Mountain Valley Pipeline, LLC, 140 S. Ct. 300 (2019) (Mem.) (No. 19-54).

3. $I d$.

4. Pamela King, Va. widow leads eminent domain fight at Supreme Court, E\&E NEws (Aug. 13, 2019), https://www.eenews.net/stories/1060934045 [https://perma.cc/QAG6-BABE].
} 
land..$^{5}$ Their retirement dreams began to fracture when Mountain Valley initiated eminent domain proceedings against them. ${ }^{6}$ The couple, Karolyn and the late Clarence Givens, fought back and attempted to take their battle to the Supreme Court. ${ }^{7}$ In October 2019, that fight came to an end when the Court denied their petition for writ of certiorari. ${ }^{8}$ While this did not come as a shock - the Supreme Court denied a similar writ of certiorari in 2019 — what the Givens might not have known in the beginning is that the system is inherently against them. ${ }^{9}$

Amid strife between global political leaders and the threat of other countries' burgeoning oil and gas industries, the United States grasps on to its energy independence and remains an integral force in the global oil and gas industry. ${ }^{10}$ However, the fear of having to rely solely on U.S. adversaries like Saudi Arabia and Russia for energy creates a heightened sense of urgency in securing the U.S. oil and gas market. ${ }^{11}$ The incessant demand for oil and gas has prompted a surge of natural gas pipeline development, and with the ever-present fear of becoming energy dependent, legislators have heavily favored placing oil and gas companies in the best and easiest position possible to do business. ${ }^{12}$ As a result, the industry is booming with pipeline projects such as one in the Appalachian Basin where $\$ 32.6$ billion in investments will generate 3,500 miles of "new, repurposed or replaced pipelines across Ohio, Pennsylvania and West Virginia." 13 $54)$.

5. Petition for Writ of Certiorari at 5, Givens, 140 S. Ct. 300 (2019) (No. 19-

6. Id. at 8 .

7. King, supra note 4.

8. Charles Fishburne, Supreme Court Denies Appeal of Eminent Domain for Mountain Valley Pipeline, VPM NPR PBS (Oct. 8, 2019), https://vpm.org/news/articles/7532/supreme-court-denies-appeal-of-eminentdomain-for-mountain-valley-pipeline [https://perma.cc/3HV4-A5VJ].

9. John Kramer, U.S. Supreme Court Denies Cert in Case Dealing with Pipeline Company's Abuses of Eminent Domain, InSTITUTE FOR JUSTICE (May 28, 2019), https://ij.org/press-release/u-s-supreme-court-denies-cert-in-case-dealingwith-pipeline-companys-abuses-of-eminent-domain/ [https://perma.cc/EB8G7VSX].

10. Jude Clemente, Three Things to Know About the U.S. Oil and Natural Gas Industry, FORBES (May 15, 2019, 9:23 A.M.) https://www.forbes.com/sites/judeclemente/2019/05/15/3-things-to-know-aboutthe-u-s-oil-and-natural-gas-industry/\#2a01a9cafa67 [https://perma.cc/58JE-54DE].

11. Id.

12. Id.

13. Nicole Jacobs \& Dan Alfaro, Infographic: More Than $\$ 32$ Billion Being 
However, these pipeline projects, like all things, come at a cost. ${ }^{14}$ The burden of the robust natural gas pipeline industry is carried on the backs of private landowners, like the Givens, who would have never once imagined their land would be taken by the U.S. government, much less a natural gas pipeline company. ${ }^{15}$ Private landowners have been deprived of their property without receiving just compensation before the taking and have sometimes gone years without seeing a penny from the natural gas companies. ${ }^{16}$

The Natural Gas Act ("NGA") outlines the process in which natural gas companies can seize private land for public use through standard condemnation proceedings. ${ }^{17}$ However, the majority of district courts grant preliminary injunctions to natural gas companies, allowing them to enter and use the land before a trial on just compensation. ${ }^{18}$ This begs the question of whether the courts are going beyond the powers delegated to them in the NGA. ${ }^{19}$

In an effort to rein in the courts, there have been two attempts to have the Supreme Court take up this issue in 2019 alone. ${ }^{20}$ This Note will evaluate the most recent attempt in the Fourth Circuit case of Givens v. Mountain Valley Pipeline. Specifically, this Note will focus on two questions: (1) whether there is a circuit split that would warrant Supreme Court intervention and (2) whether it is in the power of the courts to issue a preliminary injunction before a trial on just compensation. The Note agrees with the petitioners in Givens arguing that there is a circuit split that should be evaluated by the Supreme

Invested in Appalachian Basin Pipelines, ENERGY IN DEPTH (Feb. 28, 2019), https:/www.energyindepth.org/infographic-more-than-32-billion-being-investedappalachian-basin-pipelines/ [https://perma.cc/2MTB-79DB].

14. John Kramer, New Findings: Pipeline Companies Flout Law Nationwide, Take Land Without First Paying Property Owners, InSTITUTE FOR JUSTICE (Apr. 8, 2019), https://ij.org/press-release/new-findings-pipeline-companies-flout-lawnationwide-take-land-without-first-paying-property-owners/

[https://perma.cc/E3X8-KQF9].

15. Id.

16. RJ Vogt, Land Grab: Property Owners Fight Back Against Pipeline IOUs, LAW 360 (April 28, 2019, 8:02 PM), https:/www.law360.com/articles/1153244 [https://perma.cc/KK4B-MLWQ].

17. Id.

18. Jeremy P. Hopkins \& Elizabeth M. Hopkins, Separation of Powers: A Forgotten Protection in the Context of Eminent Domain and the Natural Gas Act, 16 REGENT U.L. REV. 371, 373 (2004).

19. Petition for Writ of Certiorari at 24, Givens v. Mountain Valley Pipeline, LLC, 140 S. Ct. 300 (2019) (No. 19-54).

20. Vogt, supra note 16. 
Court, and the courts are beyond the bounds of the NGA in issuing preliminary injunctions before a trial on just compensation. This Note evaluates whether the courts are following the provisions of the NGA, not whether the courts are going beyond the bounds of the Constitution. ${ }^{21}$

Section II will provide the statutory and case law backdrop to Givens. It will provide an overview of the natural gas pipeline's authority to exercise eminent domain under the NGA and a summary of the process pipeline companies go through to obtain the ability to condemn private property under the NGA. This section will also explain the development of case law on this issue, along with a more in-depth understanding of how the circuit split developed. Section III will define the circuit split and describe in detail the primary cases that outline the split.

Section IV will elaborate on the Supreme Court developments on this issue. It will describe the recent attempts to bring this issue to the Supreme Court. This section will argue that the Court needs to adopt the approach of the Seventh Circuit. Lastly, this section will explore the pipeline company's rights at the time a court grants a preliminary injunction and how the courts have exceeded their discretion in granting these preliminary injunctions.

\section{BACKGROUND}

\section{A. The Natural Gas Act and Eminent Domain}

The NGA enables certain private entities in the energy industry, like natural gas pipeline companies, to exercise eminent domain. ${ }^{22}$ The authority to exercise eminent domain rests with the legislature; however, Congress can delegate this authority to private entities. ${ }^{23}$ When Congress delegates this power, it must do so expressly, and the power granted must not be greater "than those expressed or necessarily implied." ${ }^{24}$ In other words, private entities

21. For further reading on the constitutionality of the Court's actions under the NGA please refer to Hopkins \& Hopkins, supra note 18 at 371.

22. 15 U.S.C. $\S 717 \mathrm{f}(\mathrm{h})(2006)$.

23. Jim Behnke \& Harold Dondis, The Sage Approach to Immediate Entry by Private Entities Exercising Federal Eminent Domain Authority Under the Natural Gas Act and the Federal Power Act, 27 ENERGY L.J. 499, 502 (2006).

24. Id. 
with delegated eminent domain power are limited to exercise eminent domain within the scope that Congress has expressly specified in the enabling statute. ${ }^{25}$ Standard eminent domain and quick-take are the two main types of eminent domain procedures. ${ }^{26}$ The NGA authorizes pipeline companies to use standard eminent domain procedures. ${ }^{27}$

The NGA authorizes the Federal Energy Regulatory Commission ("FERC") to regulate the natural gas industry. ${ }^{28}$ The FERC regulates natural gas projects, the interstate transmission of natural gas, and other energy issues related to electricity and gas. ${ }^{29}$ The Commission sets out the procedure for regulatory approval, including obtaining right of ways from private landowners. ${ }^{30}$ Therefore, the FERC is responsible for providing an appropriate process for pipeline companies to obtain eminent domain authority. ${ }^{31}$ It does so by overseeing and implementing the application process to obtain a certification of "public convenience of necessity." 32 The NGA requires public convenience and necessity certification of all pipeline companies engaging in the transportation or sale of natural gas. ${ }^{33}$ This certification's purpose is to create a threshold level of necessity that pipeline companies must meet to exercise eminent domain. ${ }^{34}$ However, once a certificate is issued, it does not automatically give the pipeline company the authority to enter the property immediately, such as in a quick-take proceeding. ${ }^{35}$ Pipeline companies still have to go through standard eminent procedures. ${ }^{36}$ While only two pipeline projects have been denied their pipeline proposals over the past thirty years, the process of obtaining the proper authority to exercise standard eminent domain powers is elaborate, overwhelming, and

25. Hopkins \& Hopkins, supra note 18 , at 379-80.

26. Victoria Mazzola, Comment, Putting the Pieces of the Puzzle Together: The Natural Gas Pipeline Approval Process is a Procedural Jigsaw, 64 VILL. L. REV. 459, 467 (2019).

27. $I d$.

28. $\$ 717 \mathrm{o}$.

29. About FERC, FED. ENERGY REG. COMMISSION, https://www.ferc.gov/about/what-ferc [https://perma.cc/6AHJ-2UX7].

30. Mazzola, supra note 25 , at 464.

31. $\S 717 \mathrm{o}$.

32. $\$ 717(d)$.

33. $\S 717(\mathrm{c})(1)(\mathrm{a})$.

34. Behnke \& Dondis, supra note 23, at 502.

35. $I d$.

36. $§ 717 \mathrm{f}(\mathrm{h})$. 
lengthy for pipeline companies, much less private landowners, to navigate. ${ }^{37}$

When a company is interested in constructing a new interstate pipeline, the first step is to apply for certification of public convenience with the FERC. ${ }^{38}$ The application includes a description of the pipeline, a statement of the facts explaining why the pipeline is necessary, and an approximate start and end date of the construction of the pipeline.$^{39}$ Once the application is submitted, the FERC's experts, including professionals in the scientific, legal, and economic fields, evaluate factors relating to the pipeline's cultural and environmental impacts. ${ }^{40}$ Then, the FERC submits the application for public comment. ${ }^{41}$ When the project becomes open for public comment, private property owners who might be affected by the pipeline are notified by mail that their property may be subject to eminent domain proceedings. ${ }^{42}$ Following public comment, the FERC conducts public hearings on the proposed application. ${ }^{43}$ The FERC then reviews the application as a whole and decides whether to accept the application. ${ }^{44}$ During this process, the pipeline company can make changes to the pipeline route, and the company is not required to have secured all the necessary state and federal permits. ${ }^{45}$ If the FERC approves the pipeline company's application for certification, the company and the citizens affected by the construction begin negotiations regarding compensation price and easement agreements. ${ }^{46}$

At this stage, when private landowners refuse to sell or negotiate with pipeline companies, which occurs often, pipeline companies can file condemnation actions against the private landowners in a federal district court. ${ }^{47}$ The NGA delegates jurisdiction to federal courts to decide eminent domain cases. ${ }^{48}$ In

37. Mazzola, supra note 25 , at 463-64.

38. Id. at 469 .

39. § $717 \mathrm{f}(\mathrm{d}) ; 18$ C.F.R. 153.7 (2020).

40. Mazzola, supra note 25, at 469.

41. Id.

42. $I d$.

43. $§ 717 \mathrm{f}(\mathrm{d})$.

44. Mazzola, supra note 25, at 469 .

45. Id. at 470 .

46. Id.

47. Id. at 467.

48. Behnke \& Dondis, supra note 23, at 502. 
granting jurisdiction, the NGA outlines the procedures the court must use to determine how immediate entry and other issues related to eminent domain should be resolved. ${ }^{49}$ The federal courts have abided by a three-prong elemental test outlined in the NGA. ${ }^{50}$ The elements are as follows: (1) the party must have obtained a FERC certificate of public convenience and necessity; (2) the party has attempted but failed to acquire the substantive rights required to "construct, operate, and maintain a FERC-approved pipeline" because the private property owners and the pipeline company cannot reach an agreement; and (3) the property value sought must be over $\$ 3,000 .^{51}$

While the courts follow these procedures, the issue here is that the courts might be undermining the authority the NGA has delegated to them. One of the chief arguments of landowners involved in these suits is that the courts are impliedly allowing quick-take procedures while no legislative authority has expressly allowed the courts to do so and, therefore, disregarding standard eminent domain procedures. ${ }^{52}$ In a standard eminent domain procedure, the party preparing to condemn the property files a condemnation action in one proceeding, and the court determines the amount of compensation at a separate proceeding after the condemnation proceeding. ${ }^{53}$ At the compensation proceeding, the party bringing the condemnation action decides to either purchase the property at the determined price or dismiss the action. ${ }^{54}$ The title does not pass until after the condemning party pays just compensation to the appropriate property owner, and then the condemning party can seize the property. ${ }^{55}$

In comparison, quick-take procedures are harsh and intrusive because of the government's swift action in obtaining the land. ${ }^{56}$ In a quick-take proceeding, the condemning party files a "Declaration of Taking" and deposits what it assumes the monetary value of the property to be with the court. ${ }^{57}$ Once the condemning party completes

49. Id.

50. Mazzola, supra note 25 , at 467.

51. Id.; see 15 U.S.C. $§ 717 \mathrm{f}(\mathrm{h})(2006)$.

52. E. Tenn. Nat. Gas Co. v. Sage, 361 F.3d 808, 824 (4th Cir. 2004).

53. Mazzola, supra note 25, at 468.

54. Hopkins \& Hopkins, supra note 18, at 384.

55. Id. at $386-87$.

56. Id. at 372 .

57. Mazzola, supra note 25, at 468. 
this two-step process, the party may seize the property, and they have obtained title to the land. ${ }^{58}$

Typically, as seen in most of the cases on this issue, after the pipeline company has obtained the FERC certificate, the company initiates eminent domain proceedings against resisting landowners. ${ }^{59}$ Routinely, the pipeline company moves for "summary judgment on its substantive right to take the easements by eminent domain" and requests a preliminary injunction for access and possession during the proceedings ${ }^{60}$ Landowners could argue that this current procedure resembles quick-take procedures because when the court grants a preliminary injunction before a trial on just compensation, it allows the pipeline company to enjoy all the benefits of having title to the property before a trial on just compensation. ${ }^{61}$ In other words, the preliminary injunction grants the pipeline company immediate access, bypassing the necessary procedures of a standard eminent domain proceeding, and it postpones the just compensation phase until after the party exercising condemnation has received possession of the property. ${ }^{62}$ This procedure raises the question of whether the courts are complying with the NGA because the NGA does not expressly state that quick-take procedures or immediate possession are permitted. ${ }^{63}$

\section{B. The Development of Pipeline v. Property Owner Cases}

The two main approaches to pipeline condemnation proceedings have developed over the past few decades. The attitudes of the courts towards eminent domain have evolved since the first time a court denied immediate entry to a private company possessing eminent domain authority in 1957. ${ }^{64}$ In Algonquin Gas Transmission v. Herman Yules, a natural gas company held a certificate of public

58. $I d$.

59. James W. Adams, Craig D. Stocker, \& Lynne M. Jurek, The Business of Gas Pipeline Condemnation: A Multistate Analysis, 13 Hous. BUS. \& TAX L.J. 128, 142.

60. Mountain Valley Pipeline v. 6.56 Acres of Land, 915 F.3d 197, 210 (4th Cir. 2019).

61. Hopkins \& Hopkins, supra note 18, at 380 .

62. Id. at 405 .

63. Transcon. Gas Pipeline Co., LLC v. Permanent Easement for 2.14 Acres, 907 F.3d 725, 736 (3d Cir. 2018).

64. Behnke \& Dondis, supra note 23 , at 542 . This unpublished case is only available in the files of The Sage Approach authors. 
convenience and necessity issued by the now-defunct Federal Power Commission (the FERC has taken over the role of the Federal Power Commission). ${ }^{65}$ The gas company argued that the court could exercise its inherent equity discretion and grant the gas company immediate entry before a trial on just compensation. ${ }^{66}$ The court ultimately denied the petition for immediate entry. ${ }^{67}$ However, the court noted that there may be circumstances where granting immediate entry would be suitable. ${ }^{68}$ In denying the petition, the court found that the pipeline company suffered minimal prejudice, and this result avoided harm to the landowner. ${ }^{69}$

Pipeline eminent domain issues were not litigated again until the early $1980 \mathrm{~s}^{70}$ At this time, courts took a turn that has endured through the decades and is central to this Note. Courts began to exercise their equity jurisdiction in deciding these cases. ${ }^{71}$ For example, in 1981, a district court decided that it could exercise its inherent powers to provide equitable relief; therefore, the court granted the pipeline company the right to enter the land before a trial on just compensation. ${ }^{72}$

In Northern Border Pipeline Co. v. 127.79 Acres of Land, the pipeline company obtained a FERC certificate of public convenience and sought "immediate possession of the right of way and easements" of the land at issue. ${ }^{73}$ The pipeline company argued that it was entitled to immediate possession through equitable relief. ${ }^{74}$ The court reasoned that the pipeline company was entitled to equitable relief because it satisfied both parts of the two-prong test for equitable relief. ${ }^{75}$ In the first step, the plaintiff must demonstrate that either the "primary right ... must be equitable rather than legal or the remedy sought must be equitable." ${ }^{\prime 76}$ In the second step, the plaintiff must articulate that it is

65. Id. at $525-26$.

66. $I d$. at 526 .

67. Id. at $526-27$.

68. $I d$. at 500 .

69. Id.

70. Id. at 525 .

71. N. Border Pipeline Co. v. 127.79 Acres of Land, 520 F. Supp. 170, 172 (D.N.D. 1981).

72. Id. at 173 .

73. Id. at 171 .

74. Id.

75. Id. at 173 .

76. Id. at 172 . ("If the legal remedy is inadequate, the court may exercise its equitable jurisdiction."). 
"subject to imminent, irreparable injury in the absence of a grant of equitable relief." 77 The court found that the pipeline company demonstrated that the legal remedy, a standard condemnation proceeding, was "inadequate under the circumstances." company explained that it would not be able to meet its construction deadlines and budget if it had to go through the standard condemnation proceeding. ${ }^{79}$ Construction personnel was ready to initiate construction in the disputed area, which made immediate possession necessary. ${ }^{80}$ The court recognized these reasons as sufficient and granted equitable relief on the condition that the pipeline company deposited the estimated cost of just compensation with the court's registry. ${ }^{81}$

In light of this case, it is important to note that the court here recognized that the pipeline company did not have the authority under the NGA to exercise immediate possession "prior to a condemnation proceeding." ${ }^{\circ 2}$ That power only rests with the federal government, and "no statutory authority exists" that would enable the plaintiffs to exercise this power. ${ }^{83}$ However, the court still decided that the pipeline company was able to obtain immediate possession through equitable relief, which set the standard of these cases for years to come. ${ }^{84}$

The division between pipeline eminent domain approaches hit a milestone in 1998. The Seventh Circuit denied immediate entry to a pipeline company in Northern Border Pipeline Co. v. 86.72 Acres of Land. ${ }^{85}$ In this case, the court reasoned that it could not exercise equitable relief in favor of the pipeline company ${ }^{86}$ In 2004, the Fourth Circuit took an opposing view in East Tennessee Natural Gas Co. v. Sage. ${ }^{87}$ The court held that it could provide injunctive relief and

77. Id.

78. Id. at $172-73$.

79. Id. at 172 .

80. Id.

81. Id. at 173 .

82. Id. at 172 .

83. $I d$.

84. Id. at 173.

85. N. Border Pipeline Co. v. 127.79 Acres of Land, 144 F.3d 469, 471-72 (7th Cir. 1998) (affirming the district court's holding that "Northern Border "has no legal right to immediate possession under either federal substantive law or Illinois substantive law"').

86. Id. at 471.

87. E. Tenn. Nat. Gas Co. v. Sage, 361 F.3d 808, 828 (4th Cir. 2004) (holding that "the court may exercise equitable power to grant the remedy of immediate 
granted the pipeline company the right of immediate entry. ${ }^{88}$ Since the Sage decision, the majority of circuit courts have followed the Sage approach. ${ }^{89}$ Only the Seventh Circuit has stood by the rule articulated in Northern Border Pipeline Co. v. 86.72 Acres of Land. ${ }^{90}$

\section{THE CIRCUIT SPLIT}

The chief issue in these cases is simple but creates a cloud of confusion regarding how the federal courts should handle this issue. After a pipeline company obtains a FERC certificate, the majority of U.S. district courts have granted a preliminary injunction in favor of the pipeline companies to take the land before a trial on just compensation. ${ }^{91}$ However, the NGA does not expressly allow for immediate possession before a trial on just compensation, and it could be argued that the NGA impliedly denies the court the ability to grant a preliminary injunction. ${ }^{92}$ The conflict that has arisen between the circuit courts centers around the question of whether the court can issue a preliminary injunction without the express authority from the NGA-it is a statutory construction issue, not a question of constitutionality. ${ }^{93}$

\section{A. The Fourth Circuit Sage Approach}

Sage outlines the approach that favors granting a preliminary injunction and allowing pipeline companies to operate on the land before a trial on just compensation. ${ }^{94}$ In Sage, the East Tennessee Natural Gas Company was constructing a pipeline "over 1,300 tracts of land in Tennessee, Virginia, and North Carolina." ${ }^{95}$ After negotiating with hundreds of landowners and initiating 133 landowners were still fighting condemnation..$^{96}$ In these proceedings, the company filed motions for immediate possession of the easements

possession through the issuance of a preliminary injunction").

88. Id. at 828 .

89. Vogt, supra note 16.

90. $I d$.

91. Id.

92. Hopkins \& Hopkins, supra note 18, at 373.

93. Mountain Valley Pipeline, LLC v. 6.56 Acres of Land, 915 F.3d 197, 213 (4th Cir. 2019).

94. Behnke \& Dondis, supra note 23, at 544.

95. E. Tenn. Nat. Gas Co. v. Sage, 361 F.3d 808, 819 (4th Cir. 2004).

96. Id. at $819-20$. 
and argued that the court could exercise equitable relief. ${ }^{97}$ The district court held that it could use its inherent powers to grant a preliminary injunction, an equitable remedy. ${ }^{98}$ The court relied on the fact that stalling the construction of the pipeline would lead to an "extended delay." 99 The landowners filed an appeal with the Fourth Circuit, arguing that the NGA does not grant the pipeline companies the ability to obtain immediate possession because the statute does not include the ability to use quick-take proceedings. ${ }^{100}$ Additionally, the court must construe eminent domain statutes strictly and, therefore, could not invoke equity principles. ${ }^{101}$

Sage severed the FERC certification right to take the land from the trial of just compensation. ${ }^{102}$ In doing so, it only reviewed the FERC certification for the pipeline's right to condemn. ${ }^{103}$ Here, the court held that the use of a preliminary injunction was appropriate where the district court had determined that the FERC certificate established the pipeline company's right to exercise eminent domain. ${ }^{104}$ The court noted that a preliminary injunction provides sufficient procedural safeguards for landowners that are even more protective than a quick-take proceeding. ${ }^{105}$

Regarding the landowner's second argument, the court reasoned that a strictly construed statute does not bar the court from exercising the principles of equity. ${ }^{106}$ The court pointed out that the landowners overlooked the overwhelming public interest the pipeline serves. ${ }^{107}$ The Sage court rendered a preliminary injunction with equity because it determined that the pipeline company met the requirements for a mandatory preliminary injunction, and it is likely that the pipeline would be granted the condemnation right in the future because of the FERC certification. ${ }^{108}$

\footnotetext{
97. Id. at 820 .

98. $I d$.

99. Id.

100. Id. at $820,822,824$.

101. Id. at 826 .

102. Petition for Writ of Certiorari at 19-20, Givens, 140 S. Ct. 300 (No. 19-54).

103. Sage, 361 F.3d at 820 .

104. Id. at 823 .

105. Id. at $825-26$.

106. Id. at 826 .

107. Id.

108. Id. at $818,830,828$.
} 
In sum, the Sage approach requires that: (1) the pipeline company demonstrates it has the right to take under the FERC; (2) the conditions for preliminary injunctive relief are satisfied and mandatory; and (3) the landowner's compensation is adequately secured. ${ }^{109}$ In evaluating whether to grant the preliminary injunction, the court looks to four factors: "(1) the likelihood of irreparable harm to the plaintiff if the injunction is denied, (2) the likelihood of harm to the defendant if the injunction is granted, (3) the likelihood the plaintiff will succeed on the merits, and (4) the public interest." 110 Preliminary injunctions are almost always granted because the interstate pipelines serve an overwhelming public need to supply energy and hold on to U.S. energy independence. ${ }^{111}$ Additionally, courts have reasoned that the pipeline companies will face irreparable harm if they are required to wait for a trial on just compensation. ${ }^{112}$

\section{B. The Seventh Circuit Northern Border Pipeline Approach}

The Seventh Circuit remains the outlier on this question. ${ }^{113}$ In Northern Border Pipeline Co. v. 86.72 Acres of Land, the Seventh Circuit held that the court had no authority to issue a preliminary injunction because the Northern Border Pipeline Company had no preexisting entitlement to the land. ${ }^{114}$ In this case, the pipeline company obtained a FERC certificate, because the company was "not content with the pace of ordinary eminent domain proceeding[s]," so it moved for immediate possession of the property. ${ }^{115}$ The pipeline company argued that the court should grant a mandatory preliminary injunction. ${ }^{116}$ The district court denied the pipeline company's request, and the pipeline company appealed. ${ }^{117}$ On appeal, the circuit court affirmed the district court's decision. ${ }^{118}$ The court reasoned that a

109. Behnke \& Dondis, supra note 23, at 502.

110. Sage, 361 F.3d at 828.

111. See Transcon. Gas Pipe Line Co. v. Conestoga Twp., 907 F.3d 725, 733 (3d Cir. 2018) (finding that the project was in the public interest "further tipped this factor in favor of Transcontinental"); id. at 830; N. Border Pipeline Co. v. 127.79

Acres of Land, 520 F. Supp. 170, 172 (D.N.D. 1981).

112. Vogt, supra note 16.

113. Id.

114. 144 F.3d 469, 472 (7th Cir. 1998).

115. Id. at 470 .

116. Id. at 471.

117. Id.

118. Id. 
preliminary injunction was only available "when the moving party has a substantive entitlement to the relief sought." 119 While the company argued that it has a substantive right to the property through its eminent domain power under the NGA, the court hinged its decision on the fact that the company's rights were not "fully vested before the initiation of the lawsuit." ${ }^{\prime 20}$ In other words, without a preexisting right to the land, the court would not issue a preliminary injunction. ${ }^{21}$ The Seventh Circuit's approach does not recognize a pipeline company's substantive right until it has been granted and will not grant the right to condemn based on what might happen in the future. ${ }^{122}$ While the Fourth Circuit interprets the FERC as granting a substantive right, the Seventh Circuit recognizes that this right is granted after the proceeding on just compensation. ${ }^{123}$

\section{The Supreme Court Should Provide Clarity}

There has been pushback from pipeline companies on this split. In Mountain Valley's brief in opposition to the petition for writ of certiorari, it argued that there is no circuit split. The company argued that the Seventh Circuit approach evaluates a completely different area of the law and that the Seventh Circuit agrees with the Sage approach. ${ }^{124}$ Mountain Valley argued that the Seventh Circuit did not even reach this issue because the pipeline company asserted it had a substantive right based solely on its FERC certificate of public convenience and did not initiate standard eminent domain proceedings at the district court level. ${ }^{125}$ According to Mountain Valley, and the other cases on this issue, the pipeline company based its substantive right on its FERC certificate of public convenience and the standard condemnation proceedings at the district court level after obtaining the certification. ${ }^{126}$ Mountain Valley argued that taking these two steps together gives pipeline companies the authority to exercise eminent

119. Id.

120. Id. at 471-72 ("Northern Border's right to the land do[es] not vary when the

FERC issues it a certificate").

121. Id.

122. $I d$. at 471.

123. Petition for Writ of Certiorari at 19, Givens, 140 S. Ct. 300 (No. 19-54).

124. Brief in Opposition to Petition for Writ of Certiorari at 14-15, Givens, 140

S. Ct. 300 (No. 19-54).

125. Id.

126. Id. at 14 . 
domain. ${ }^{127}$ Therefore, the Seventh Circuit did not grant the injunction because the pipeline company did not obtain orders determining its substantive right to the property before filing a motion for immediate possession. ${ }^{128}$ Mountain Valley reasoned that this would have been the same outcome in every other circuit court because each circuit agrees that there must be a "finding of authority to condemn by the district court before an immediate-possession injunction can be awarded."129

The Seventh Circuit applies a different meaning to the FERC certification. ${ }^{130}$ Karolyn Givens argued in her petition for certiorari that there is a circuit split because the FERC certification does not give companies a preexisting entitlement to possession, which is the view other circuit courts apply. ${ }^{131}$ The FERC certification allows pipeline companies to participate in the process of obtaining the substantive right, but the only way to obtain the right is to complete the entire process, including a trial on just compensation. ${ }^{132}$ Courts cannot assume that they will complete the process - they must complete it. ${ }^{133}$ The other circuits are satisfied with companies entering the process and view this as enough to obtain the rights. ${ }^{134}$ In other words, entering the process is enough to rely on for a preliminary injunction. The Seventh Circuit reasoned that granting a preliminary injunction would only be appropriate where the "substantive entitlement to the relief sought . . . was fully vested even before the initiation of the lawsuit."."135 This approach on the use of preliminary injunctions is fundamentally different than the approach other circuit courts take, which is that the FERC certificate essentially gives the pipline companies the substantive right. ${ }^{136}$ The Seventh Circuit recognizes that the FERC does not give the pipeline company any "substantive entitlement to the land right now;" therefore, the pipeline company cannot point to any

127. See id.

128. See id.

129. Id. at 15 .

130. See Reply Brief for Petitioners at 1, Givens, 140 S. Ct. 300 (No. 19-54).

131. See Transcon. Gas Pipe Line Co. v. Conestoga Twp., 907 F.3d 725, 733-36 (3d Cir. 2018).

132. Reply Brief for the Petitioners at 3, Givens, 140 S. Ct. 300 (No. 19-54).

133. Id.

134. Id.

135. Petition for Writ of Certiorari at 148-49, Givens, 140 S. Ct. 300 (No. 19-54) (emphasis added) (quoting N. Border Pipeline Co. v. 86.72 Acres of Land, 144 F.3d 469, 471-72 (7th Cir. 1998)).

136. Reply Brief for the Petitioners at 2, Givens, 140 S. Ct. 300 (No. 19-54). 
authority that gives it a substantive right, and the court cannot use a preliminary injunction to grant them immediate possession. ${ }^{137}$

In sum, a circuit split exists because the Seventh Circuit in Northern Border Pipeline Co. v. 86.72 Acres of Land placed a different meaning on the FERC certification process, and the pipeline companies are entitled to compare the legal authority to the Fourth Circuit and the other circuit courts that have followed the Sage approach. The Seventh Circuit holds that the FERC certification does not grant pipeline companies a substantive right, but the certification lets them enter the process towards obtaining a substantive right. ${ }^{138}$ The Fourth Circuit holds that the FERC certification essentially grants pipeline companies a substantive right at the time the certification is issued, and the use of a preliminary injunction hastens the enforcement of the substantive right. ${ }^{139}$

\section{SUPREME COURT DEVELOPMENTS}

As the circuit split illustrates, there is confusion among landowners about the status and security of their property. With their livelihood threatened, some landowners have fought condemnation with the hopes that the Supreme Court will change the course of the circuit and district courts. ${ }^{140}$ However, the Court denied two opportunities to resolve this dispute in 2019. ${ }^{141}$

\section{A. Recent Supreme Court Attempts}

The recent increase in pipeline development projects across the northeast has led to a surge of pipeline eminent domain litigation. ${ }^{142}$ For example, a major player in the natural gas pipeline industry, Transcontinental, was involved in five cases in federal circuit courts in 2018, compared to only six from 1989 to $2017 . .^{143}$ The recent pipeline construction proposals have led to disruption in rural communities, and some homeowners have decided to fight back. In

137. Id.; see N. Border Pipeline Co. v. 86.72 Acres of Land, 144 F.3d 469, 47172 (7th Cir. 1998).

138. Reply Brief for the Petitioners at 3, Givens, 140 S. Ct. 300 (No. 19-54).

139. Petition for Writ of Certiorari at 11, Givens, 140 S. Ct. 300 (No. 19-54).

140. Vogt, supra note 16.

141. Kramer, supra note 9; Fishburne, supra note 8.

142. Mazzola, supra note 25, at 462.

143. Id. at $462-63$. 
2019 alone, there have been two attempts to bring this to the Supreme Court's attention. ${ }^{144}$

The first attempt came out of the Third Circuit, where the circuit court upheld the grant of a preliminary injunction and specifically looked at whether the district court effectively granted a quick-take rather than proceeding under standard eminent domain guidelines. ${ }^{145}$ The circuit court reasoned that this was not a quick-take because the pipeline company followed the proper procedures outlined for standard eminent domain at the district court level. ${ }^{146}$ Here, the landowners argued that "the use of a preliminary injunction amounted to a quick-take," and the NGA does not afford pipeline companies the authority to use quick-take procedures to obtain title to a property; therefore, the courts are usurping the power of the legislature by utilizing preliminary injunctions in this way. ${ }^{147}$ In response, the court reasoned that quick-take procedures and the use of preliminary injunctions have "meaningful distinctions in law." because the pipeline company had obtained a FERC public convenience certification, it already obtained the substantive right to enter the property. ${ }^{149}$ The use of a preliminary injunction "hastened the enforcement of the substantive right - it did not create new rights." 150

Regardless of whether the use of a preliminary injunction amounts to quick-take, the landowners also argued that the NGA does not provide for immediate possession, which preliminary injunction necessarily produces. ${ }^{151}$ The court's response to this was that the NGA does not specify that the "rules governing preliminary injunctions should be suspended in condemnation proceedings." 152 In other words, the NGA does not get rid of this equitable remedy, and courts are within their authority to exercise this power, regardless of whether it amounts to immediate possession. ${ }^{153}$ In sum, the district court did not

144. Vogt, supra note 16.

145. Transcon. Gas Pipe Line Co. v. Conestoga Twp., 907 F.3d 725, 729 (3d Cir. 2018).

146. Id.

147. Id. at 734 .

148. Id. at 735 .

149. Id. at 729,735 .

150. Id. at $735-36$.

151. Id. at 738 .

152. Id.

153. $I d$. 
usurp legislative authority in granting the preliminary injunction, and the NGA does not rule out the use of preliminary injunctions. ${ }^{154}$

The second attempt, which is the primary focus of this Note, is from the Fourth Circuit in Mountain Valley Pipeline v. 6.56 Acres of Land. The central question in the case was whether the pipeline company could gain access to the easements at moment it received FERC certification or if it had to wait until a trial on just compensation to start construction. ${ }^{155}$ The district court held that the pipeline company did not have to wait until the court determined just compensation and affirmed the district court's decision to grant the company a preliminary injunction to access the easements and begin construction. ${ }^{156}$

Courts use a four-pronged test when determining whether to grant a preliminary injunction, and here, the court found that Mountain Valley satisfied all four elements. ${ }^{157}$ The first element is the likelihood of success on the merits, which Mountain Valley easily satisfied because it had the right to condemn the landowner's property, and Mountain Valley obtained the substantive right to the property through a partial summary judgment at the district court level. ${ }^{158}$ The second element is whether the party would suffer irreparable injury, and the court reasoned that Mountain Valley would suffer irreparable injury because the extremely long delay in construction would likely hinder Mountain Valley from meeting its October 2020 deadline mandated by the FERC..$^{159}$ The court believed this element was important because if Mountain Valley had to wait until the determination of just compensation for the hundreds of landowners involved in this case, it would be well past the October 2020 deadline set out by the FERC and would cost Mountain Valley millions of dollars to stall construction. ${ }^{160}$ The third element is a balance of equities, and here, the court found the losses suffered by Mountain Valley far exceeded whatever harm the landowners suffered as a result of the preliminary injunction. ${ }^{161}$ Additionally, the landowners identified harms that "would be inflicted

154. Id. at 740 .

155. 915 F.3d at 209.

156. $I d$.

157. Id. at $216,219,221$.

158. Id. at 216.

159. $I d$.

160. Id. at 217.

161. Id. at 220 . 
as a result of the eminent domain itself," not because of the preliminary injunction. ${ }^{162}$ The last element focuses on public interest, and in relying on the report issued by the FERC, the court determined the project would serve a public need. ${ }^{163}$

The plaintiffs here argued that the appellate court should overrule the Sage decision because the NGA does not allow for immediate possession. ${ }^{164}$ The landowners asserted that by expressly providing for standard condemnation proceedings, the NGA forecloses the possibility that courts can grant possession "through the equitable remedy of a preliminary injunction." 165 The circuit court did not adopt this approach and held that Sage governed-allowing the court to grant the pipeline company a preliminary injunction, an equitable remedy. ${ }^{166}$

In July 2019, property owners in the Mountain Valley case filed a writ of certiorari to the Supreme Court, arguing that preliminary injunctions were an improper use of federal jurisdictional power. ${ }^{167}$ The Court denied certiorari in October 2019, bringing only more confusion to the situation. ${ }^{168}$ While both attempts have failed, this demonstration of efforts points toward an ever-growing interest in clarifying a pipeline company's authority in exercising eminent domain and whether that authority complies with the NGA.

The future of pipeline eminent domain litigation hangs in the balance after the Supreme Court recently denied certiorari for Givens v. Mountain Valley Pipeline. While a denial of certiorari lets the appellate decision stand, it does not indicate that the Court agrees with the result of the case. ${ }^{169}$ Whether the Supreme Court agrees with the way the lower courts are deciding these cases is up for debate, and it is highly possible that these recent attempts will continue to grow in number as more pipeline projects continue to expand across the United States.

162. Id. at 212 .

163. Id.

164. Id. at $214-15$.

165. Id. at 214 .

166. Id. at 215.

167. Petition for Writ of Certiorari at 3, Givens, 140 S. Ct. 300 (No. 19-54).

168. Givens v. Mountain Valley Pipeline, 140 S. Ct. 300 (2019) (Mem.).

169. Peter Linzer, The Meaning of Certiorari Denials, 79 COLUM. L. REV. 1227, 1303 (1979). 


\section{B. The Supreme Court Should Adopt the Seventh Circuit Approach}

The Sage approach may exceed the bounds outlined in the NGA. Courts have continued to adopt this approach in the interest of efficiency but ultimately to the detriment of private property owner's rights. In order to safeguard private property rights, courts should follow the clear guidelines of the NGA, which do not give pipeline companies the authority to obtain immediate possession of the property. Additionally, to prevent altering the substantive rights of the parties, courts should stop granting mandatory preliminary injunctions in these pipeline-landowner cases. For these reasons, the Supreme Court should take up this issue and adopt the Seventh Circuit approach.

\section{The NGA Does Not Authorize Immediate Possession}

The NGA is an unambiguous statute-it expressly provides that standard eminent domain proceedings are allowed, but it is silent on whether the courts should allow immediate possession in the form of a preliminary injunction, which closely imitates quick-take proceedings. ${ }^{170}$ The statutory construction canon expressio unius strongly favors the exclusion of this provision. Expressio unius is a well-settled statutory construction tool, and it means that "expressing one item of [an] associated group or series excludes another left unmentioned." 171 In utilizing this tool, the court must look at the context of the statute, and this canon has more force when the party can show that Congress excluded the provision by "deliberate choice, not inadvertence." 172 The NGA provides for standard condemnation proceedings but does not mention the more intrusive quick-take proceedings that are reserved only for governmental use. The landowners could argue here that the drafters of the NGA specifically excluded exceptions to the standard eminent domain proceeding because the NGA only mentions standard eminent domain proceedings and is silent on quick-take proceedings or the use of any other methods to grant immediate possession. The court could

170. Mazzola, supra note 25, at 467; see also Natural Gas Act, 15 U.S.C. $\S$ $717 \mathrm{f}(\mathrm{h})(2018)$.

171. N.L.R.B. v. SW General, Inc., 137 S. Ct. 929, 940 (2017) (quoting Chevron U.S.A. Inc. v. Echazabal, 536 U.S. 73, 80 (2002)).

172. Id. (quoting Marx v. Gen. Revenue Corp., 133 S. Ct. 1166, 1175 (2013) (citing Bruesewitz v. Wyeth LLC, 562 U.S. 223, 232-33 (2011))). 
consider the exclusion of quick-take proceedings and other forms of immediate possession as a deliberate choice because these methods are often more intrusive and specifically reserved for the federal government. ${ }^{173}$ Opponents will likely argue that leaving out a provision for immediate possession is mere inadvertence. However, looking at the context of the statute, one could argue that in a proceeding where a third-party deprives a private citizen of his property, the court should read the statute narrowly.

In Northern Border Pipeline Co. v. 127.79 Acres of Land, the court reasoned that the condemnation proceeding under the given circumstances was inadequate. ${ }^{174}$ However, while the court found this proceeding inadequate, this is exactly what Congress intended. Congress alone has the power to delegate eminent domain authority, and with that power, Congress is the only branch of government that can define eminent domain proceedings. ${ }^{175}$ Here, the court is taking this power into its own hands by creating an expedited method for condemnation. If Congress wanted to create an expedited method for condemnation proceedings "where the condemner takes the property before trial and pays the court-determined price later," it could. ${ }^{176}$ That is not the case here, and the court should rely on the default rule and not give early access to the pipeline companies. ${ }^{177}$

Most importantly, and the essential difference between the two approaches, is that the court is granting a substantive right before it exists. Once just compensation is paid, the pipeline companies have the substantive right to exercise eminent domain. ${ }^{178} \mathrm{Up}$ until that point, they do not have a vested right in the private landowner's property. ${ }^{179}$ The NGA expressly gives the power of the Takings Clause to pipeline companies once they have obtained the necessary certifications. ${ }^{180}$ The NGA specifies the process in which this occurs, and here, the statute

173. Hopkins \& Hopkins, supra note 18, at 372-73.

174. N. Border Pipeline Co. v. 127.79 Acres of Land, 520 F. Supp. 170, 172 (D.N.D. 1981).

175. First English Evangelical Lutheran Church of Glendale v. Los Angeles Cty., 482 U.S. 304, 321 (1987); see Seacombe v. Milwaukee \& St. P.R. Co., 90 U.S. 108, 118 (1874).

176. Petition for Writ of Certiorari at 13, Givens, 140 S. Ct. 300 (No. 19-54).

177. Kirby Forest Indus., Inc. v. United States, 467 U.S. 1, 15-16 (1984).

178. Mazzola, supra note 25 , at 476.

179. N. Border Pipeline Co. v. 86.72 Acres of Land, 144 F.3d 469, 471 (7th Cir. 1998).

180. Mazzola, supra note 25, at 475. 
provides for standard condemnation proceedings, meaning that the right is conferred after just compensation has been provided. ${ }^{181}$ The Supreme Court should adopt the Seventh Circuit approach because it appropriately recognizes that the court cannot grant immediate possession before the substantive right fully vests. This is the approach that is squarely within the bounds of the NGA and most closely follows congressional intent.

\section{Courts Have Exceeded the Limits of Equity}

Equity must still follow the law, and courts must not grant a remedy that is beyond what a party is entitled to. ${ }^{182}$ However, in these cases, the court accomplishes this by granting a preliminary injunction. The court grants the pipeline company a substantive right it is not entitled to at the time of the ruling. ${ }^{183}$

While the NGA gives jurisdiction to the district courts in condemnation proceedings, district courts rely on Federal Rule of Civil Procedure ("FRCP") Rule 65 and the judiciary's inherent equitable powers to grant preliminary injunctions. ${ }^{184}$ FRCP Rule 65(a) provides an equitable, injunctive remedy in a NGA condemnation proceeding. ${ }^{185}$ Pipeline companies have to "apply under Rule 65(a) for a preliminary injunction awarding immediate possession." 186 The inherent power of the court is defined as "those powers "necessary to the exercise of all others." 187 This doctrine is grounded in the Constitution, and the courts have utilized this power since the judiciary's inception. ${ }^{188}$ However, the exercise of these powers is not limitless. ${ }^{189}$ While there are efforts to regulate the use of this power, it is by no means "uniform." 190

181. 15 U.S.C. $§ 717 \mathrm{f}(\mathrm{h})(2006)$.

182. Hopkins \& Hopkins, supra note 18, at 3792.

183. Petition for Writ of Certiorari at 15, Givens, 140 S. Ct. 300 (No. 19-54).

184. Behnke \& Dondis, supra note 23, at 502; see Petition for Writ of Certiorari at 15 , Givens, 140 S. Ct. 300 (No. 19-54).

185. E. Tenn. Nat. Gas Co. v. Sage, 361 F.3d 808, 824 (4th Cir. 2004).

186. Id.

187. Young v. U.S. ex rel. Vuitton et Fils S.A., 481 U.S. 787, 820 (1987).

188. Hopkins \& Hopkins, supra note 18, at 397-98.

189. Id. at 398.

190. Jeffrey Jackson, Judicial Independence, Adequate Court Funding, and Inherent Judicial Powers, 52 MD. L. REV. 217, 253 (1993). 
Equity must follow the law, and courts cannot impose remedies that expand the party's legal entitlements. ${ }^{191}$ Principally, the Rules Enabling Act demands that when courts employ the federal rules, they cannot "abridge, enlarge, or modify any substantive right." 192 The federal courts cannot "displace a [s]tate's definition of its own rights and remedies." ${ }^{193}$ However, that is what the courts are doing here by stripping away still intact state-property rights before title has passed. Here, the courts are expediting the right to the property and modifying the right by placing it in the pipeline company's possession right now as compared to in the future. Courts utilize preliminary injunctions to maintain the same position of the parties while litigation proceeds. ${ }^{194}$ However, in pipeline-landowner cases, the court irreversibly alters the position of the parties when issuing a preliminary injunction. After a preliminary injunction, the landowners must allow the pipeline company to begin construction.

Further, it is important to note that courts are issuing mandatory preliminary injunctions. ${ }^{195}$ A mandatory preliminary injunction requires affirmative action on the part of the nonmoving party, the landowner. ${ }^{196}$ Courts typically disfavor mandatory preliminary injunctions because they are an extraordinary remedy. ${ }^{197}$ A mandatory preliminary injunction requires a heightened burden for the moving party, the pipeline company, in demonstrating the necessary factors for a preliminary injunction. ${ }^{198}$ When courts grant mandatory preliminary injunctions, they disrupt the status of landowners because the landowners must allow the pipeline company

191. Douglas v. Indep. Living Ctr. of S. Cal. Inc., 565 U.S. 606, 619-20 (2012); see Petition for Writ of Certiorari at 15, Givens, 140 S. Ct. 300 (No. 19-54).

192. 28 U.S.C. $\$ 2072$ (b) (1990).

193. Shady Grove Orthopedic Assoc., P.A. v. All-State Ins. Co., 559 U.S. 393, 418 (2010) (Stevens, J., concurring). Stevens concurred on the narrowest grounds, and the majority of courts of appeals follow this concurrence. E.g., Whitlock v. FSL Mgmt., LLC, 843 F.3d 1084, 1091 n.2 (6th Cir. 2016).

194. Benisek v. Lamone, 138 S. Ct. 1942, 1945 (2018) (citing Univ. of Tex. v. Camenisch, 451 U.S. 390, 395 (1981)).

195. See E. Tenn. Nat. Gas Co. v. Sage, 361 F.3d 808, 824 (4th Cir. 2008); Mountain Valley Pipeline, LLC v. 6.56 Acres of Land, 915 F.3d 197, 211 (4th Cir. 2019); Transcon. Gas Pipe Line Co. v. Constega Twp., 907 F.3d 725, 734-35 (3d Cir. 2018).

196. N. Nat. Gas Co. v. L.D. Drilling, Inc., 759 F. Supp. 2d 1282, 1298 (D. Kan. 2010)

197. Id.

198. Id. (citing Little v. Jones, 607 F.3d 1245, 1251 (10th Cir. 2010)). 
to enter their land, whereas a standard preliminary injunction does not require the plaintiff to take affirmative action. ${ }^{199}$

Lastly, while some may argue that simply placing the property rights in the hands of those who will inevitably obtain them does not modify the right, this view overlooks the importance of timing in property rights. The timing of property rights is a significant factor in every property relationship. ${ }^{200}$ If the Supreme Court adopted the Seventh Circuit approach, it would ensure that courts do not modify the substantive rights of the pipeline companies before they come into possession.

\section{CONCLUSION}

The Givens likely never expected to be embroiled in a fight against a pipeline company about the right to use and the right to exclude on their land. What they once believed to be a cautious, conservative retirement investment turned into a nation-wide debate centered on fundamental property rights. Sometime in the future, Karolyn Givens will receive the money that Mountain Valley owes her, but there is no definite timeline, and she will receive the money well after the pipeline company has done the damage to her property.

The unmatched development of natural gas pipelines has come at a cost too high for private landowners that are often left with no other option of fighting back. While it is important to serve the interests of the general public, especially in the context of energy, the burden heavily infringes on private landowner's property rights. There is a circuit split because the Fourth Circuit recognizes the pipeline company's right to condemn upon completion of the FERC certification, while the Seventh Circuit does not recognize it until after a trial on just compensation. Courts should adopt the Seventh Circuit approach because issuing a preliminary injunction is beyond the powers of the judiciary in this context. These injunctions essentially create a substantive right for the pipeline company when the company is not yet entitled to it. Due to the high cost that the current method imposes on private citizen's property rights, the Supreme Court should provide clarity moving forward. Additionally, the judiciary's role in this process should reflect what the NGA specifically intends. The

199. Id.

200. Petition for Writ of Certiorari at 17, Givens, 140 S. Ct. 300 (No. 19-54). 
Supreme Court should take up this issue to prevent any further infringement on Congress's power to administer the Takings Clause. 